\title{
Potensi Internet of Things (IoT) dan Ragam Sensor untuk Layanan Kesehatan
}

\author{
Helmy Fitriawan ${ }^{1}$, Dikpride Despa ${ }^{2}$, Ika Kustiani ${ }^{3}$ \\ Program Profesi Insinyur, Universitas Lampung \\ J1. Prof. Sumantri Brojonegoro No.1 Bandar Lampung 35145 \\ ${ }^{1}$ helmy.fitriawandeng.unila.ac.id \\ ${ }^{2}$ despa@unila.ac.id \\ ${ }^{3}$ ika.kustiani@unila.ac.id
}

Intisari - Teknologi Internet of Things (IoT) mempunyai potensi yang sangat tinggi untuk diimplementasikan dan diintegrasikan ke dalam sistem telemedicine. Sistem ini memungkinkan untuk mengawasi pasien secara real-time di rumah, dengan menggunakan berbagai macam sensor untuk membaca beragaram parameter kesehatan atau perangkat terpasang pada tubuh untuk memantau informasi medis secara real-time. Data dan informasi medis kemudian dikirimkan ke server atau komputasi awan melalui Internet yang kemudian digunakan oleh dokter dan paramedis untuk analisis lebih lanjut. Makalah ini memaparkan potensi penggunaan IoT pada layanan kesehatan dan berbagai macam parameter kesehatan yang dapat dibaca dan dianalisis oleh berbagai sensor.

Kata kunci - Internet of Things (IoT), Sensor, Klinik, Pemantauan, Kesehatan.

Abstract - Internet of Things (IoT) has very potential to be implemented and integrated in modern telemedicine systems. This system enable real-time patients monitoring at home, using various sensors to read many health parameters or wearable device that allow real-time monitoring of the medical information. This medical information are transmitted to the server or cloud via Internet and used by the doctors or paramedics for further analysis. This paper presents the potency of IoT for healthcare and various medical parametrs to be read by numerous sensors.

Keywords - Internet of Things (IoT), Sensor, Clinic, Monitoring, Health.

\section{PENDAHULUAN}

Internet of Things (IoT) merupakan suatu teknologi yang mendukung konektifitas semua benda seperti komputer, telepon pintar, sabak elektronik (tablet), Televisi pintar, perangkat rumah dengan sensor, aktuator dan perangkat lunak. Konektifitas ini membuat perangkat-perangkat tersebut dapat berkomunikasi dan bertukar data melalui infrastruktur jaringan yang tersedia seperti Internet. Setiap perangkat dengan identitas unik terhubung dengan perangkat lain membangun bentuk baru komunikasi antara orang dengan orang, antara orang dengan benda, dan antara benda dengan benda [1]. IoT merupakan suatu teknologi yang terdiri dari teknik akuisisi data di lingkungan di mana saja (sensor), teknologi komunikasi (jaringan sensor, komunikasi device-to-device, komunikasi machine-to- machine), komputasi kabut (gerbang IoT) dan komputasi awan (cloud) [2].

Diantara berbagai aplikasi atau penerapan dari IoT adalah di bidang layanan kesehatan pintar (smart healthcare). Sensor dan aktuator yang didukung dengan modul komunikasi, baik terpasang ditubuh atau diinstal di lingkungan, dapat mengumpulkan informasi kesehatan mental dan fisik. Penyediaan layanan kesehatan berbasis IoT yang andal dapat memungkinkan perluasan akses, peningkatan kualitas dan penurunan biaya layanan kesehatan [3]. Berdasarkan karakteristik unik pasien, layan kesehatan dan dukungan pasien menjadi bentuk layanan kesehatan yang terpersonalisasi. Sehingga layanan kesehatan personal harus mempunyai peningkatan kepuasan untuk membuat layanan menjadi efektif. Teknologi IoT mempunyai kemampuan untuk mempersonalisasi layanan kesehatan dan 
memelihara informasi secara digital bagi setiap pasien.

\section{SENSOR PENGUKUR PARAMETER KesEHATAN}

Tubuh manusia dapat memancarkan sinyal elektromagnetik yang mampu dideteksi oleh sensor. Pada dasarnya tubuh manusia terdiri dari sel yang terbuat dari atom. Setiap atom mempunyai medan listrik yang ketika mendekati atom lainnya yang berdekatan akan mempengaruhi medan listrik atom lainnya tersebut. Sensor digunakan untuk menganalisis kesehatan pasien dengan mengukur berbagai macam parameter tubuh. Sensor sebaiknya berukuran kecil dan tidak merusak tubuh pasien ketika mendapatkan nilai parameter dari tubuh pasien. Beragam sensor dapat digunakan untuk mengukur parameter fisiologis tubuh berikut [4]:

\section{A. Suhu Tubuh}

Perubahan pada suhu tubuh biasanya diikuti oleh sejumlah penyakit yang dierita pasien. Dengan mengukur suhu tubuh, penyebab penyekait tertentu dapat ditemukan serta pengobatan akurat dapat diberikan pada pasien. Pengukuran suhu tubuh secara langsung dilakukan menggunakan kontak transduser seperti termokopel, termistor atau suatu semikonduktor aktif.

\section{B. Resistansi Kulit}

Setiap orang biasanya mempunyai resistansi kulit yang berbeda. Perbedaan resistansi kulit bergantung pada bagaimana kontak dilakukan, apakah dari tangan ke tangan, tangan ke kaki, kaki ke kaki, dan sebagainya. Keringat adalah konduktor terbaik karena mempunyai kandungan tinggi garam dan mineral. Pengukuran resistansi tangan atau tubuh yang lebih berkeringat akan lebih rendah dibanding dengan tangan atau kulit yang kering. Keluarnya keringat merupakan respon terhadap rangsangan emosional. Sehingga, kondisi emosi seorang pasien dapat dideteksi dengan mengukur resistansi kulit melalui pengukuran pada dua lokasi titik pada tubuh.

\section{Aliran Udara Pernapasan}

Tingkat pernapasan merupakan salah satu indikator awal dari ketidakstabilan fisiologis utama. Sehingga pemantauan laju aliran pernapasan sangat penting dalam menunjukkan status pasien. Sensor aliran udara dapat digunakan memantau laju aliran udara dalam pernapasan terutama pasien yang bermasalah dengan pernapasan. Senor bekerja berdasarkan dispersi termal dan mengadopsi metode suhu diferensial konstan untuk mengukur udara pada laju alira yang sangat rendah.

\section{Tekanan Darah}

Tekanan darah adalah tekanan ketika darah dipompa oleh jantung ke seluruh bagian tubuh melalui arteri. Detak jantung membuat tekanan pada arteri yang kemudian memompa darah ke seluruh tubuh. Tekanan darah dicatat dengan dua parameter, yaitu sistolik (saat jantung berdetak) dan diastolik (saat jantung rileks diantara denyut). Tekanan darah untuk orang normal adalah sekitar 120/80. Tekanan darah akan naik jika aliran darah terhambat. Apabila tekanan darah meningkat tidak terdeteksi maka terdapat resiko tinggi beberapa masalah medis. Sehingga, informasi tekanan darah setiap saat sangat kritis terutama bagi pasien darah tinggi. Dari waktu ke waktu tekanan darah berubah dan bervariasi disebabkan faktor seperti pola pernapasan, posisi tubuh dan kondisi emosi. Tekanan darah dapat diukur menggunakan alat tensimeter atau sfigmomanometer.

\section{E. Glukosa Darah}

Penentuan kandungan glukosa darah secara otomatis, cepat, dan tepat diperlukan bagi penderita diabetes. Dokter atau paramedis umumnya menyarankan pasien dengan diabetes mellitus untuk memantau glukosa darah dengan tepat untuk menjaga keadaan aktivitas pasien secara mendekati normal. Pola perubahan glukosa darah dapat membantu pasien dalam pengaturan pola makanan, aktivitas, dan waktu untuk minum obat.

\section{F. Aktifitas Jantung}

Elektrokardiogram adalah alat diagnostik yang secara rutin digunakan untuk menilai 
fungsi elektrik dan otot jantung. Jantung dapat dianggap terdiri dari dua sistem, yaitu sistem kelistrikan yang menghasilkan kontrak impuls ritmis dan sistem mekanis yang merespon impuls ini dengan kontraksi ritmis. Terdapat berbagai metode untuk menilai aktivitas jantung. Beberapa diantaranya noninvasif (seperti auskultasi dada untuk mengevaluasi katup, elektrokardiografi untuk mengevaluasi karaketristik listrik, dan berbagai teknik pengolahan citra untuk menilai tindakan pemompaan mekanis) dan yang lainnya memerlukan beberapa instrumen invasif.

\section{G. Aktifitas Otot}

Teknik untuk merekam dan mengevaluasi akitivitas listrik yang dihasilkan otot adalah electromyography (EMG). Otot pada tubuh manusia layaknya seperti mesin memberikan tenaga. Sehingga, informasi aktivitas otot memberikan pengetahuan komprehensif mengenai kinerja manusia. Sistem neouromuskuler bersama dengan tulang, ligamen, sendi, adalah tenaga penggerak dari mesin manusia yang bertanggung jawab atas produksi daya, transmisi, dan kontrol gerakan.

\section{H. Posisi Pasien}

Pada beberapa pasien tertentu, seperti pasien dengan sindrom apnea tidur atau kaki gelisah, dibutuhkan pemantauan gerakan dan posisi tubuh. Pengamatan gerakan saat tidur membantu dalam menentukan kualitas tidur dan pola tidur yang tidak teratur. Sensor posisi tubuh digunakan untuk mendeteksi pingsan atau jatuh pasien lanjut usia.

\section{KLASIFIKASI IMPLEMENTASI IOT}

Implementasi IoT pada layanan kesehatan personal dapat diklasifikasi menjadi perawatan di klinik (clinical care) dan pemantauan secara jarak jauh (remote monitoring).

\section{Perawatan Klinik}

Kualitas layanan kesehatan di klinik sangat penting bagi pasien diopname di klinik atau rumah sakit yang sedang memulihkan diri dari penyakit berat atau operasi. Biasanya, laporan perlakukan pasien diinformasikan melalui lembar form yang dicetak atau ditulis tangan oleh dokter. Teknologi IoT dapat digunakan untuk sistem pemantauan pasien yang dirawat dimana kondisi mental dan kesehatannya perlu membutuhkan perhatian secara konstan. Sistem pemantauan ini menggunakan sensor untuk membaca informasi fisiologis pasien untuk kemudian dikirim dan disimpan ke server internal atau komputasi awan (cloud). Informasi ini kemudian dikirimkan ke dokter atau paramedis untuk analisis lebih lanjut. Sistem ini menyediakan aliran informasi yang bersifat terus menerus atau kontinyu. Dengan perhatian yang intensif tersebut dapat meningkatkan kualitas layanan kesehatan yang kemudian diikuti dengan penurunan biaya layanan dan menghilangkan kebutuhan paramedis yang dibutuhkan secara aktif dalam hal pengumpulan data kesehatan.

\section{J. Pemantauan Jarak Jauh}

Di beberapa negara berkembang, terdapat keterbatasan akses yang siap sedia dan cukup untuk layanan kesehatan yang efektif. Hal ini disebabkan jumlah doktor yang kurang dan infrastruktur kesehatan yang tidak memadai. Jaringan sensor nirkabel (JSN) berukuran kecil tetapi kuat yang terhubung melalui teknologi IoT memungkinkan untuk memantau pasien secara jarak jauh. Sejumlah ragam sensor dapat digunakan untuk menangkap data pasien dan mengirimkannya melalui hubungan jaringan nirkabel. Doketer dan paramedis profesional kemudian membaca data tersebut dan memberikan rekomendasi yang diperlukan secara jarak jauh. Pemantauan secara jarak jauh merupakan teknologi yang memungkinkan pemantauan pasien diluar klinik atau rumah sakit secara konvensional. Dimana hal ini akan meningkatkan akses terhadap layanan kesehatan dan menurunkan biaya penyampaian layanan kesehatan.

\section{PENUTUP}

Beberapa tahun terakhir jumlah penderita penyakit kronis meningkat yang disebabkan oleh meningkatnya usia hidup tetapi diiringi perubahan gaya hidup (makanan, aktivitas, 
dll) yang jauh dari sehat. Orang-orang dengan penyakit tersebut memerlukan pemantauan parameter kesehatan mereka secara intensif dan terus-menerus. Teknologi IoT menyediakan akses baru untuk perawatan dan layanan kesehatan secara efektif dengan mengembangkan dukungan instrumen penting baik bagi pasien dan dokter. Makalah ini menyajikan potensi besar yang dimiliki oleh teknologi IoT dan menggambarkan berbagai macam paramater kesehatan yang dapat dibaca oleh ragam sensor.

\section{REFERENSI}

[1] G. Kortuem, et.al. "Smart objects as building blocks for the internet of things", Internet Computing, IEEE, vol. 14, pp. 44$51,2010$.

[2] I. Ungurean and A. Brezulianu, "An Internet of Things Framework for Remote Monitoring of the Healthcare Parameters", Advance in Electrical and Computer Engineering, vol. 17, No. 2, pp. 11-16, 2017.

[3] J David Niewolny. 18 Oct 2013. How the Internet of Things is Revolutionarizing Healhtcare, Freescale Semiconductors.

[4] I. Orha and S. Oniga. "Wearable sensor nework for health monitoring uisng e-Health platform", Internet Computing, IEEE, vol. 14, pp. 44-51, 2010. 